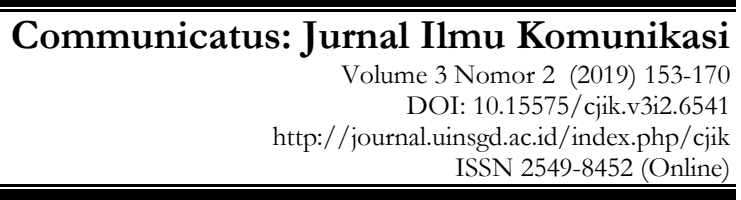

\title{
Analisis Semiotika tentang Penggambaran Orang Pedalaman pada Film Indonesia
}

\author{
Maria Rosalia ${ }^{1 *}$, Nanang Krisdinanto $^{2}$, \& Brigitta Revia Sandy Fiesta ${ }^{3}$ \\ ${ }^{123}$ Universitas Katolik Widya Mandala Surabaya \\ *email.mariawake@yahoo.co.id
}

\begin{abstract}
This study was conducted to see how inland people were described using Ferdinand de Saussure's semiotic methods. As a knife of analysis will be used the concept of blackness developed by Ed Guerrero to see aspects of behavior, intelligence, and emotions of the minority groups depicted in the film. The films analyzed are Sokola Rimba and Lost in Papua. The results showed that Indonesian films with the theme of education and social always attached the minority with the impression of being stupid, primitive and backward. In the category of behavior (behavior), inland people tend to be displayed close to backwardness (primitive) or evil. While intelligent (intelligence), they are described as having low intelligence or stupid, and emotionally (emotionally) are described as people close to violence. The research implications are expected to be a reference in the process of socially identifying tribes in the interior of Papua. Academically, this research is a space for the actualization of social semiotic analysis in Indonesia.
\end{abstract}

Keywords : film, inland people, behavior, intelligence, emotion.

\begin{abstract}
ABSTRAK
Kajian ini dilakukan untuk melihat bagaimana orang-orang pedalaman digambarkan dengan menggunakan metode semiotika milik Ferdinand de Saussure. Sebagai pisau analisis akan digunakan konsep blackness yang dikembangkan Ed Guerrero untuk melihat aspek perilaku, kecerdasan, dan emosi dari kelompok minoritas yang digambarkan dalam film. Film yang dianalisis adalah Sokola Rimba dan Lost in Papua. Hasil penelitian menunjukkan, film Indonesia yang bertema pendidikan dan sosial selalu melekatkan kaum minoritas dengan kesan bodoh, primitif dan terbelakang. Dalam kategori tingkah laku (behavior), orang-orang pedalaman cenderung ditampilkan dekat dengan keterbelakangan (primitif) atau jahat. Sementara secara intelligent (kecerdasan), mereka digambarkan memiliki kecerdasan rendah atau bodoh, dan secara emotional (emosi) digambarkan sebagai orang-orang dekat dengan kekerasan. Implikasi penelitian diharapkan menjadi rujukan dalam proses identifikasi suku pedalaman Papua secara sosial. Secara akademik, penelitian ini menjadi ruang aktualisasi analisis semiotika sosial di Indonesia
\end{abstract}

Kata kunci : film, orang pedalaman, tingkah laku, perilaku, emosi. 


\section{PENDAHULUAN}

Kajian ini bertitik-tolak dari munculnya fenomena di perfilman Indonesia pada era tahun 2000-an yang memunculkan tema-tema orang pedalaman yang menjadi etnis minoritas. Tema ini menjadi menarik di tengah tren film Indonesia yang berlatar belakang situasi kota metropolitan dan kebanyakan berlokasi Pulau Jawa. Film-film bertema orang pedalaman tersebut tergambar dalam sejumlah film, seperti Denias, Senandung di Atas Awan (2006)), Tanah Air Beta (2010), Batas (2011), Lost In Papua (2011), Di Timur Matahari (2012), Sokola Rimba (2013), Atambua 39 Derajat Celcius, Marlina (2017) dan Laskar Pelangi (2008). Suku-suku yang diangkat dalam film-film ini adalah Papua (Wamena dan Korowai), Sulawesi Tenggara (Bajo), NTT (Atambua dan Sumba), dan Jambi (Orang Rimba).

Film-film tersebut menggambarkan situasi orang pedalaman kerap ditampilkan selalu hidup berdampingan dengan alam dan masih berpegang teguh pada budaya. Selain itu, film-film tersebut juga menampilkan keseharian hidup orang pedalaman yang dikaitkan dengan teknologi, sosial, ekonomi, kesehatan, pendidikan serta lainnya. Tidak hanya situasi kehidupan, film-film tersebut pun pun kerap menggambarkan sikap dan tingkah laku orang pedalaman.

Selain film di atas, terdapat sejumlah film Indonesia yang sebetulnya tidak mengangkat tema orang pedalaman, namun menggunakan karakter orang pedalaman sebagai “aksesoris,"seperti Ngenest (2015), Stip and Pensil (2017), Susah Sinyal (2017), Jomblo Reboot (2017), Catatan Akhir Kuliah (2015), Relationshit (2015), Cek Tokoh Sebelah (2016), Get Up Stand Up (2016), Target (2018), dan Flight 555 (2018). Film Susah Sinyal, misalnya, mengisahkan seorang ibu tunggal (single mom) yang mengajak putrinya berlibur ke Sumba, sebuah daerah yang digambarkan terbatas akan berbagai akses. Meskipun begitu, Sumba memiliki alam yang cantik. Pada film ini, karakter orang pedalaman digambarkan berada dalam ranah pekerjaan "rendahan," yakni supir dan budak yang selalu tunduk kepada atasannya. Tidak hanya itu, film ini menampilkan orang pedalaman sebagai bahan lelucon.

Orang pedalaman merupakan konsep tentang suatu kelompok yang bisa dilihat secara fisiologis yakni melalui jenis kelamin, usia (tua muda), dan ras (hitam putih). Kriteria lain bisa dilihat dari kebudayaannya. Dalam hal ini, menurut Kinloch (Sunarto, 2004: 142), mereka diikat oleh persamaan seperti etnik seperti Aceh, Minangkabau, Ambon, Dayak dan sebagainya. Hubungan antar kelompok etnis ini dibagi dalam dua kelompok, yakni mayoritas dan minoritas. Di sini muncul unsur relasi kuasa, karena kelompok mayoritas misalnya selalu menganggap dirinya normal. Sedangkan perilaku kelompok minoritas dianggap tidak normal karena memiliki ciri tertentu berdasarkan anggapan dari kelompok lain yang mengalami ekploitasi dan diskriminasi. Ciri yang dimaksud ialah ciri fisik, ekonomi, budaya dan perilaku dari etnis atau kelompok tersebut.

Secara luas media cenderung membuat gambaran-gambaran tersebut 
melalui berbagai informasi yang dimuat secara visual maupun audio visual. Media juga sering kali menggambarkan hal yang melekat pada identitas ras tertentu seperti yang dikemukakan Wallace mengenai orang Papua yang memiliki ciri fisik yaitu warna kulit gelap kecokelatan dan rambut kering serta ikal (Widjaja, 2012: 1). Berdasarkan pengamatan penulis, film-film yang mengangkat etnis Papua yakni Denias, Senandung di Atas Awan (2006), Di Timur Matahari (2012), atau Lost In Papua (2011) menampilkan kehidupan orang Papua yang terikat kuat pada nilai budaya, terjadi karena budaya memang dianggap bernilai, berharga serta penting dalam hidup. Misalnya, ritual potong jari yang masih dijalankan orang pedalaman Papua yang dimaknai sebagai tanda duka ketika ada anggota keluarga yang meninggal, dengan menampilkan realitas-realitas tersebut, media membuka peluang terbentuknya berbagai persepsi khalayak mengenai etnis tersebut. (Koentjaraningrat, 2009: 153).

Media membangun stereotip yang mampu memengaruhi serta mengubah pola pikir khalayak mengenai kehidupan orang-orang pedalaman. Stereotip merupakan cara pandang terhadap suatu kelompok sosial (Mufid (2009: 260-261). Dalam konteks film, di satu sisi memang merupakan cerminan situasi hidup, tetapi di sisi lain memengaruhi atau memberi gagasan, ide atau nilai-nilai budaya lain kepada masyarakat atau kelompok yang berbeda (Wibowo, 2016). Relasi media dengan realitas berlangsung dalam enam tahapan, Pertama, tahap awal ketika tekhne mewujud dalam bentuk komunikasi lisan. Kedua, ketika tekhne berlangsung melalui komunikasi lisan, pada tahap ini komunikasi lisan tersebut melahirkan pandangan dunia (worldview) yang ditransmisikan melalui tulisan. Ketiga, tahap ini berlangsung ketika tekhne menggandakan dirinya melalui sistem simbol. Keempat, tekhne menemukan perangkat baru berupa gelombang elektromagnetik. Kelima, tekhne mulai melakukan pengemasan atau pembingkaian melalui proyeksi gambar. Keenam, adalah tahap dimana tekhne hadir melalui sistem komputer digital yang tidak bisa dipungkiri lagi (Rustandi, 2018: 208-209).

Kajian ini menjadi penting, karena ingin mendeteksi atau mengurai bagaimana orang pedalaman digambarkan ditampilkan dalam film-film Indonesia, yang diproduksi oleh sineas-sineas yang Jakarta (Pulau Jawa) yang bisa dilihat sebagai bagian dari kelompok mayoritas. Penggambaran (representasi) ini memang terkoneksi dengan stereotip karena bukan hanya berhubungan dengan fisik, namun makna di balik tampilan tersebut (Wibowo, 2016: 1066). Kajian ini ingin memberi pengetahuan kepada khalayak mengenai situasi dan keadaan orang pedelaman, karena tidak semua yang digambarkan dalam media sesuai keadaan yang sebenarnya.

Aspek yang dianalisis adalah tanda-tanda dalam teks (film), maka kajian ini menggunakan metode semiotika yang dikembangkan Ferdinand de Saussure, yang memiliki sistem tanda yang tersusun atas dua tingkatan yakni signifier dan signified. 
(Vear, 2014:19). Saussure menekankan relasi antar dua komponen yang tak dapat dipisahkan tersebut. Sementara film yang dianalisis adalah Sokola Rimba yang bertema pendidikan dan Lost in Papua yang bertema sosial. Kedua film ini menarik karena menggambarkan realitas tentang orang pedalaman yang menjadi etnis minoritas di Indonesia yang berlokasi di luar Jawa yakni Jambi dan Papua. Pisau analisis yang adalah konsep atau teori yang dikembangkan Ed Guerrero tentang blackness, yang kemudian melihat gambaran kelompok minoritas dari aspek, yaitu behavior (tingkah laku), intelligence (kecerdasan), dan emotion (emosi).

Kajian ini menggunakan konsep blackness yang dikembangkan Guerrero (1993) saat menganalisis penggambaran orang-orang kulit hitam (Afro-Amerika) dalam film-film Hollywood. Gambaran itu diuraikan Guerrero dengan menggunakan tiga kategori, yaitu behavior (tingkah laku), intelligence (kecerdasan), dan emotion (emosi). Pada kategori behavior, orang kulit hitam digambarkan memiliki sifat komikal, penghibur, seorang atlet, dan bisa juga kriminal (Guerrero, 1993: 7). Guerrero juga menyatakan orang kulit hitam selalu digambarkan sebagai seseorang yang tidak beradab dan tidak pernah berpikir panjang dalam bertindak. Dalam konteks emotion, orang kulit hitam digambarkan memiliki sifat ragu-ragu dan selalu merasa tak bisa mendapatkan sesuatu yang diharapkan dalam mengatasi masalah. Ketiga, intelligence, orang kulit hitam ditampilkan memiliki tingkat intelengensi lebih rendah dibanding kaum kulit putih, maka dari itu orang kulit hitam lebih cenderung mengandalkan emosi dibanding logikanya (Guerrero, 1993:123). Intelligence pun merupakan sebuah kemampuan mental seseorang yang meliputi cara berhitung, penalaran, mengamati hubungan dan analogi, belajar cepat, menyimpan dan mengambil informasi, menggunakan bahasa, mengklasifikasi, generalisasi dan menyesuaikan dengan situasi baru.

Ras menjadi pembahasan sangat penting dan berhubungan dengan emosi seseorang atau kelompok yang bermuatan politik dan memiliki imajinasi tersendiri pada media Amerika. Kekuatan ras ini terbukti dengan adanya berbagai cara yang telah digambarkan oleh media dan pengalaman orang Amerika Afrika dan ras lainnya yang digambarkan secara simbolis melalui tontonan bioskop (Guerrero, 1993: 41).

Rasisme sangat memiliki hubungan yang kuat dengan perbedaan warna kulit hitam dan putih di Amerika Serikat. Orang berkulit putih menganggap dirinya lebih memiliki keunggulan dibanding orang kulit hitam yang bisa mendiskriminasi dengan bebas ras kulit hitam. Karena itu orang kulit hitam selalu menjadi minoritas di Amerika yang selalu berusaha bisa sejajar dengan ras kulit putih. Orang kulit hitam yang menjadi minoritas ini merupakan keberhasilan perfilman Hollywood dalam membangun gambaran atau citra kaum Afro Amerika yang selalu ditampilkan sebagai orang yang terpinggirkan dan dibatasi dengan representasi dalam stereotip (Guerrero, 1993:9-10).

Guerrero menunjuk tahun 1969-1974 sebagai era dimulainya Blaxplotation 
dalam film-film Hollywood. Hal ini misalnya ditandai dengan penggunaan aktoraktor berkulit hitam dengan tema perbedaan ras. Blaxploitation dikatakan memiliki hubungan yang erat penggunaan orang-orang kulit hitam sebagai money maker (pencetak uang) untuk industri perfilman Hollywood yang dikuasai orang-orang kulit putih. Meskpun film tersebut sanagat populer pada masanya, namun genre dari film tersebut didisintegrasi karena sarat streotype (Guerrero, 1993: 69-70). Filmfilm Blaxploitation yang diproduksi Hollywood ini merupakan bagian dari strategi pemasaran untuk memulihkan industri perfilman dan krisis ekonomi dengan target pemirsanya orang-orang yang tinggal di kota (Guerrero, 1993: 31).

Film sendiri, dalam kajian media, dilihat sebagai subjek yang mengkonstruksikan realitas yang lengkap dengan pandangan bias dan keberpihakan. Karena itu media dianggap sebagai agen konstruksi sosial yang menggambarkan realitas (Yusuf, 2005: 8). Berkaitan dengan realitas yang ditampilkaan, media bukan hanya realitas yang tertunda namun realitas yang tersunting. Artinya, ada pemilahan mengenai informasi baik informasi yang penting dan tidak penting serta informasi yang dianggap penting, namun demi kepentingan survival tidak disebarluaskan. Di sini media menjadi kontrol informasi yang bukan semata-mata dicita-citakan, namun yang mampu memengaruhi dan meyakinkan pikiran-pikiran khalayak (Sobur, 2016:114).

Film juga memiliki kekuatan dan kemampuan yang bisa menjangkau banyak segmen sosial dan mempengaruhi khalayaknya. Maka dari itu film memiliki dampak terhadap masyarakat, artinya film mampu memengaruhi dan membentuk masyarakat berdasarkan pesan yang disajikan di baliknya, tanpa pernah berlaku sebaliknya. Berbagai kritik muncul bahwa film merupakan potret dari realitas masyarakat (Sobur, 2016: 127).

Kajian ini sendiri melengkapi penelitian-penelitian sebelumnya yang juga mengangkat tema-tema serupa, yaitu yang melihat penggambaran orang-orang pedalaman atau kaum minoritas dalam teks-teks film. Secara umum, kajian atau penelitian serupa cenderung menghasilkan temuan senada, yaitu adanya penggambaran yang bersifat diskriminatif, stereotipikal dan menindas secara budaya (simbolik) terhadap orang-orang pedalaman atau kaum minoritas.

Christiani (2017), misalnya, mengangkat penggambaran identitas etnis Papua dalam film Diam Diam Suka. Hasil analisis menunjukkan, film ini mengekalkan identitas Papua yang bodoh, aneh, dan primitif dengan menekankan perbedaan orang Papua terhadap mayoritas melalui penampilan, atribut budaya, dan cara berbicara. Sedangkan Melati (2014) yang melihat bagaimana film Denias, Senandung di Atas Awan mengangkat tema-tema pendidikan. Melati menemukan adanya ironi bahwa ternyata teks film ini justru "menyelamatkan" pemerintah dari kritik adanya ketidakadilan dalam aspek pendidikan di Papua. Penelitian yang dilakukan Islam (2012) juga menangkap fenomena serupa di dalam program televisi (Trans TV). Temuannya menyebutkan adanya dominasi kekuasaan 
kelompok mayoritas terhadap etnis Papua dalam penggambaran etnis tersebut dalam program televisi.

Riset-riset lain yang menyangkut penggambaran kelompok minoritas (tidak hanya orang pedalaman seperti Papua atau Orang Rimba) di dalam film juga memperlihatkan hal serupa. Riset Melissa (2013) yang mengangkat etnis Tionghoa di Indonesia, Kaya (2016) yang mengangkat kaum gay dalam film The Imitation Games, Kusuma dan Sholihah (2018) yang mengangkat etinis Tionghoa dalam film Ngenest dan Kukejar Cinta ke Negeri Cina, juga sama-sama menghasilkan gambaran yang melihat kaum minoritas sebagai other dan berada di bawah subordinasi budaya kelompok mayoritas.

Selain melengkapi riset-riset lain, kajian ini juga memberikan gambaran lebih detail tentang diskriminasi atau penindasan secara kebudayaan terhadap kelompok minoritas (orang pedalaman) dalam film. Penggunaan konsep Ed Gurrero memberi peluang kajian ini untuk membedah praktik penindasan itu dengan detail melalui tiga kategori, yaitu behavior, intelligence dan emotion. Di sinilah pentingnya kajian ini karena pisau analisisnya mampu menyajikan hasil yang lebih tajam serta detail.

\section{HASIL DAN PEMBAHASAN}

Sokola Rimba merupakan film yang diproduksi Miles Film, dengan sutradara Riri Riza dan produser Mira Lesmana. Film ini dibintangi Prisia Nasution bersama penduduk lokal dan terinspirasi dari novel berjudul Sokola Rimba. Novel ini diangkat dari kisah nyata Butet Manurung yang pernah menjadi guru di pedalaman Rimba. Butet merupakan karyawan di lembaga konservasi yang bertugas di bidang pendidikan. Film ini mengisahkan kelompok-kelompok orang rimba yang masih hidup di tengah hutan pulau Sumatra, yakni Jambi. Film menceritakan perjuangan seorang guru untuk bisa memberikan pendidikan lebih baik di pedalaman rimba.

Sedangkan film Lost in Papua disutradarai Irhamachobahtiar, dan menceritakan sebuah suku pedalaman Papua yang masih tertutup. Film ini menampilkan penduduk lokal yang beradu akting dengan aktris ibukota dengan keindahan alam Papua yang cantik. Nadia yang diperankan aktris Fanny Febriani merupakan gadis kota yang mendapat tugas dari kantor untuk masuk ke pedalaman Papua bersama timnya. Awalnya Nadia menolak pergi karena pandangannya mengenai Papua yang masih sangat primitif. Namun karena tugas dan mendapat dukungan sang kakek, Nadia memutuskan pergi ke Papua.

Merujuk konsepsi Guerrero, penulis melihat tanda-tanda yang terasosiasi dengan karakter bodoh, primitif dan menutup diri dalam sejumlah scene dalam Sokola Rimba. Penggambaran ini menunjukkan bagaimana kaum minoritas pedalaman dipandang dengan sudut pandang tertentu. Penegasan ini dilakukan melalui penggambaran karakter, sudut kamera dan penonjolan sisi tertentu dalam film tersebut. Hal ini dapat kita lihat pada tabel di bawah ini yang menggambarkan 
beberapa tanda penggambaran dengan maksud tertentu.

Tabel 1. Anak Rimba Sedang Belajar

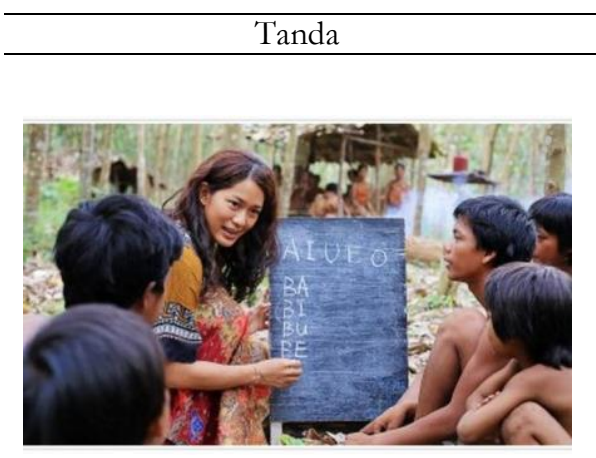

Menit 32-38

$\begin{array}{cc}\text { Penanda } & \text { Petanda } \\ \text { Anak-anak rimba } & \text { Behavior } \\ \text { bertelanjang dada dan } & \text { Digambarkan } \\ \text { bercelana pendek } & \text { primitif, karena } \\ \text { tradisional sedang } & \text { tidak } \\ \text { belajar membaca dan } & \text { berpenampilan } \\ \text { menulis bersama guru } & \text { seperti orang kota } \\ \text { (Butet) di tengah hutan. } & \text { (modern) } \\ & \text { Emotion }\end{array}$

Tidak stabil, merasa ragu bisa belajar dengan baik. Intelligence Digambarkan bodoh karena belum bisa menulis dan membaca selayaknya anak usia sekolah.

Sumber : Film Sokola Rimba

Cuplikan scene di atas terlihat sekumpulan anak pedalaman Rimba sedang mengikuti proses pembelajaran yang berlangsung di pemukiman di Bukit Duabelas Jambi. Kelompok anak rimba ini belajar menulis dan membaca huruf vokal yang diajarkan guru Butet. Pada scene ini tergambar bahwa mereka masih belajar pada tahap awal, yakni membaca dan menulis huruf vokal menggunakan papan tulis berukuran kecil, kapur secukupnya tanpa perlengkapan sekolah pada umumnya.

Hal tersebut menandakan suasana pendidikan di pedalaman rimba yang tidak memiliki fasilitas memadai dan apa adanya. Kelompok pedalaman rimba pun terkesan tidak mempedulikan pentingnya pendidikan. Hal ini dikarenakan orang pedalaman rimba sangat percaya kepada alam yang merupakan hal paling penting dibanding dengan hal lainnya. Karena itu, meski digambarkan masih ada warga yang mau belajar, namun tidak semua orang rimba ditampilkan memiliki keinginan belajar.

Scene itu juga menandakan orang-orang pedalaman sebagai kelompok primitif, karena hidup dengan kebiasaan lama tanpa ingin mengetahui situasi di luar kehidupan mereka. Hal ini di lihat dari tempat tinggal yang berlokasi di tengah hutan. Bagi orang rimba, hutan merupakan tempat tinggal yang sesungguhnya. Tidak hanya menjadi tempat tinggal, namun hutan juga merupakan sumber orang rimba memenuhi kebutuhan hidup sehari-hari. Bagi mereka hutan membantu 
mereka mencari makan dan minum. Hal inilah yang menjadi titik kontrol bagi orang rimba dalam menjaga ketaatannya terhadap adat mereka. (Saleh, 2014).

Scene ini pun orang pedalaman rimba digambarkan memiliki sikap yang masih ragu-ragu dengan pembelajaran yang diberikan Butet. Meski begitu mereka tetap mengikuti pembelajaran dengan baik. Banyak anggota kelompok digambarkan tidak terima dengan adanya pembelajaran di tempat mereka. Mereka merasa pembelajaran dapat mengubah kebiasaan atau adat yang selama ini dijaga. Hal ini dikarenakan orang rimba telah terbiasa menjalankan aturan, norma dan adat istiadat di hutan rimba selama hidup (Saleh, 2014).

Tabel 2. Anak-Anak Belajar di Pondok

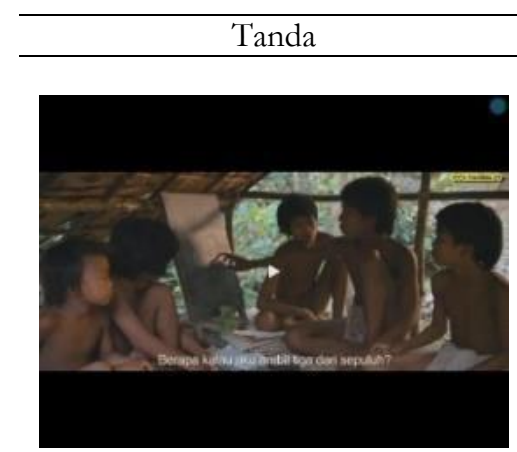

Menit 37.05
Sekelompok anak laki-laki pedalaman Rimba sedang belajar membaca di sebuah pondok.
Petanda

Behavior

Orang pedalaman

Rimba hanya memberi

izin anak laki-laki untuk belajar.

Emotion Masih mengikuti pelajaran secara perlahan.

Intelligence Digambarkan bodoh dan masih tertutup karena belum dapat menyesuaikan diri dengan kesetaraan gender dalam pendidikan.

Sumber : Film Sokola Rimba

Scene di atas tampak beberapa anak laki-laki belajar membaca yang diarahkan seorang anak lebih tua. Ini menandakan bahwa kelompok pedalaman yakni orang rimba lebih memberi kesempatan kaum laki-laki untuk menerima pendidikan di banding perempuan. Hampir tidak ada scene dalam film ini yang menunjukkan anak perempuan ikut belajar bersama guru Butet. Padahal dalam ranah sesungguhnya pendidikan bisa disamaratakan antara perempuan dan laki-laki. Namun kelompok rimba masih menggunakan kebiasaan lama, di mana ketika melakukan sesuatu, maka kaum laki-laki akan lebih diutamakan. Hal tersebut dapat dibuktikan dari beberapa scene berikut: 
Analisis Semiotika tentang Penggambaran Orang Pedalaman pada Film Indonesia
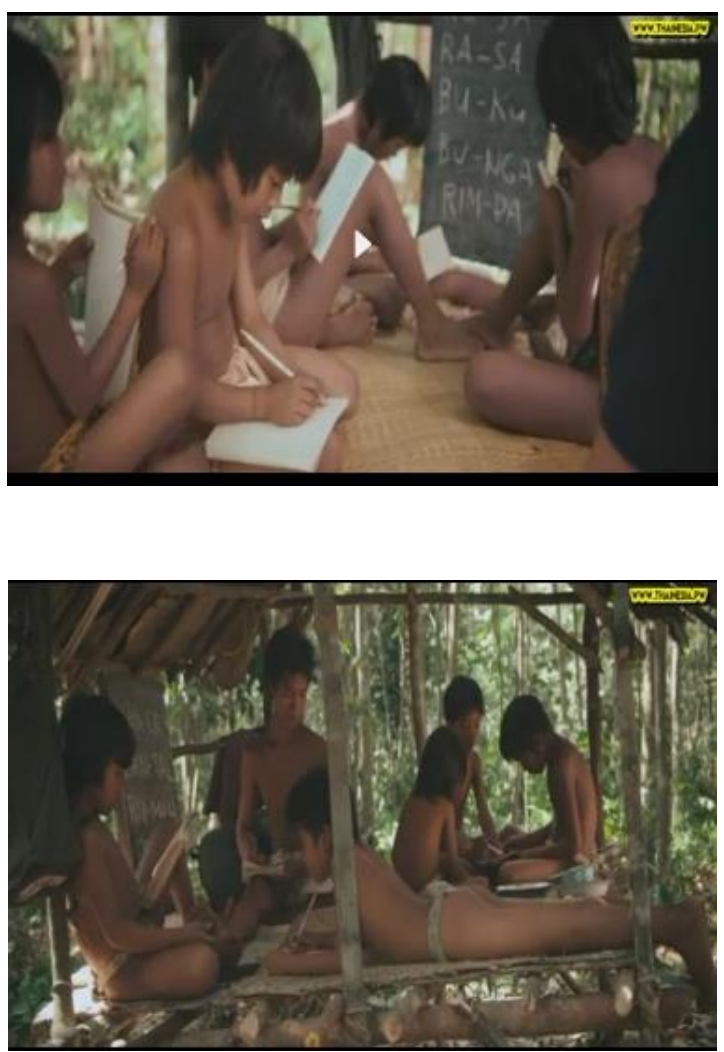

Sumber: Film Sokola Rimba

Gambar 1. Anak lelaki belajar menulis

Gambaran diskriminasi gender dalam pendidikan juga muncul dalam film orang pedalaman lain seperti Denias, Senandung di Atas Awan (2006). Hal ini terlihat dari scene yang ditampilkan dalam film tersebut yang menggambarkan orang pedalaman Papua lebih mementingkan pendidikan untuk anak laki-laki dibanding anak perempuan. Pendidikan yang didapat perempuan rimba bukanlah pendidikan formal seperti umumnya, namun pendidikan informal. Pendidikan informal dilihat dari usia perempuan tersebut. Pada umumnya perempuan pada usia 5 tahun sudah diajarkan oleh keluarganya khususnya ibunya untuk melakukan pekerjaan rumah. Contohnya, memasak, membuat tikar, dan mengasuh adikadiknya. Pada usia inipun sudah diajarkan cara berladang (Syafirin, 2014).

Penggambaran-penggambaran lainnya direpresentasikan melalui kebiasaan atau adat orang pedalaman dalam aspek tertentu. Misalnya, kebiasaan nomaden atau berpindah tempat tinggal yang ditampilkan dalam sebuah film menjadi ruang untuk menunjukkan sisi-sisi tertentu mengenai orang pedalaman. Seperti tabel di bawah ini yang menunjukkan kebiasaan nomaden orang pedalaman digambarkan dalam film Sekolah Rimba. 
Tabel 3. Kebiasan Melangun Orang Rimba

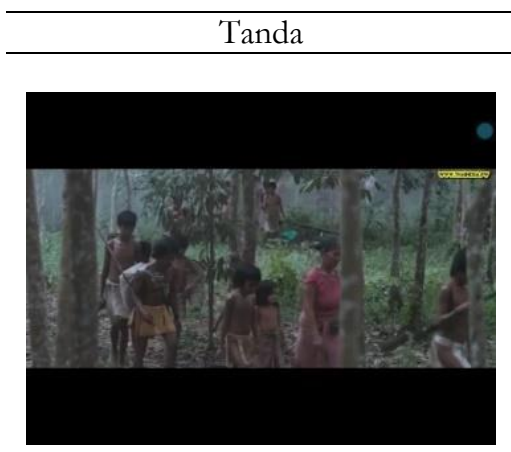

Menit 1.14.23

$\begin{array}{cc}\text { Penanda } & \text { Petanda } \\ \begin{array}{c}\text { Sekelompok orang } \\ \text { rimba berjalan di } \\ \text { tengah hutan untuk } \\ \text { mencari tempat tinggal } \\ \text { baru, dengan }\end{array} & \begin{array}{c}\text { Orang pedalaman Rimba } \\ \text { masih menggunakan tradisi } \\ \text { membawa semua } \\ \text { melangun untuk } \\ \text { bang milik mereka } \\ \text { yang biasa disebut } \\ \text { melangun. }\end{array} \\ & \text { Memidup. } \\ & \text { Emotion } \\ & \text { stabil karena tidak memiliki } \\ & \text { cara lain untuk mengatasi } \\ & \text { persoalan. }\end{array}$

Intelligence
Orang pedalaman Rimba
cenderung masih
mengandalkan kebiasaan
atau adat dan tidak
menyesuaikan dengan cara
hidup modern.

Sumber : Film Sokola Rimba

Scene di atas tampak sekelompok orang pedalaman Rimba sedang berjalan di tengah hutan. Dalam perjalanan tersebut mereka membawa semua harta benda berupa barang peralatan masak, tas, pakaian, kayu dan sebagainya. Perjalanan ini biasa disebut melangun. Melangun merupakan sebuah perjalanan panjang yang bisa menghabiskan waktu berbulan-bulan hingga bertahun-tahun.

Dapat diidentifikasi bahwa perjalanan yang dilakukan orang rimba dalam scene ini akibat salah satu anggota mereka yang telah meninggal yakni Temenggung atau kepala adat. Mereka menganggap bahwa pendidikan yang masuk dalam lingkaran hidup merekalah yang menyebabkan semua ini terjadi. Ini yang mereka namakan sebagai malapetaka. Kelompok rimba yang merupakan suku minoritas di Sumatera masih menjalankan tradisi lamanya yang tergambar dalam film Sokola Rimba. Hal ini dikarenakan mereka masih menganut sistem kepecayaan dewadewi yang akan memberikan kebaikan jika mereka menjalankan adat dengan benar.

Melangun merupakan sebuah jalan keluar bagi orang pedalaman untuk menghindari malapetaka. Melangun bisa dilakukan oleh orang pedalaman Rimba berupa perjalanan panjang untuk pergi dari tempat tinggal awal dan mencari lahan atau tempat tinggal baru. Perjalanan ini dilakukan jika salah satu dari anggota kelompok mereka telah meninggal. Hal ini dilakukan karena mereka mempercayai bahwa jika ada orang yang meninggal di tempat tersebut akan membawa masalah 
bagi anggota kelompok yang lain. Jadi untuk menghindari hal tersebut, mereka memutuskan melangun sejauh mungkin, yang bisa memakan waktu berbulanbuan hingga bertahun-tahun. Perjalanan dengan membawa semua harta benda ini pun sebagai rasa duka yang mendalam bagi anggota yang meninggal. Tujuan dari melangun inipun untuk mencari kehidupan yang lebih baik dan bisa melupakan kenangan serta rasa sedih (Sidik, 2016).

Scene ini menandakan bahwa orang pedalaman memiliki emosi tidak stabil. Mereka tak mampu mengatasi persoalan yang akan datang. Maka dari itu mereka lebih memilih pergi agar terhindar dari persoalan yang akan datang tersebut. Hal yang digunakan dengan melangun sejauh mungkin. Pada scene ini, orang pedalaman Rimba masih cenderung mengandalkan kepercayaan akan tradisi dan situasi alamnya. Kelompok ini belum mampu menyesuaikan diri dengan cara hidup modern. Hal ini dilihat dari mereka yang tidak bisa menetap di satu tempat. Mereka masih menggunakan tradisi lama yakni berpindah-pindah tempat tinggal selama hidup mereka. Hal ini berbeda dengan kebiasaan masyarakat modern pada biasanya yang selalu menetap di satu tempat pada waktu yang lama. Dalam film Lost in Papua, yang muncul juga penggambaran senada namun dengan penekanan yang berbeda.

Tabel 4. Memanah dalam Perang Suku

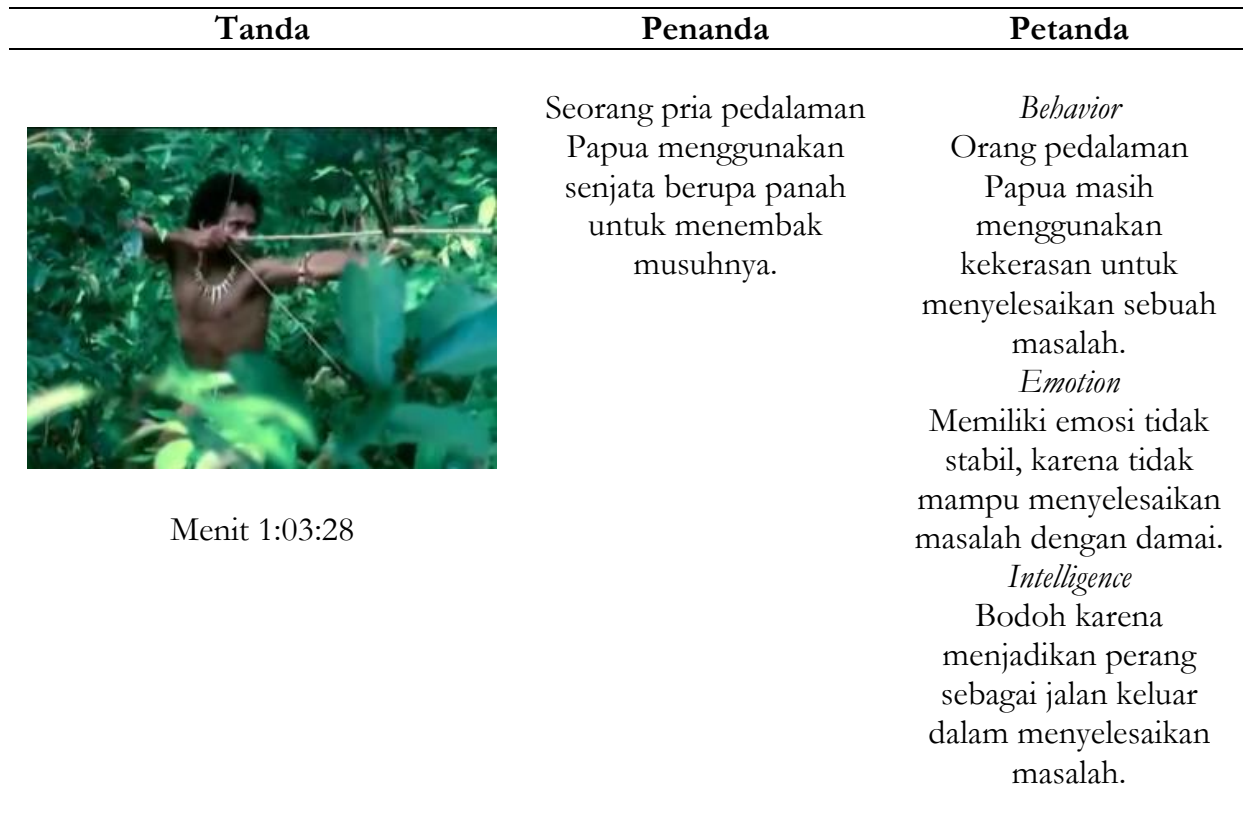

Sumber : Film Lost In Papua

Scene di atas tergambar pria pedalaman Papua berada di tengah hutan dengan memegang senjata berupa panah. Panah tersebut ia gunakan menyerang 
lawannya. Cuplikan adegan ini menunjukkan terjadi perang antar orang pedalaman Papua dengan orang asing dari kota. Sebenarnya, kelompok pedalaman melakukan perang dengan alasan mendasar. Mereka tidak terima perlakuan David yang menewaskan salah satu anggota kelompok mereka. Untuk membalasnya mereka ingin membunuh David dan kelompoknya. Kelompok yang ialah kelompok dari Suku Korowai. Korowai digambarkan dalam film ini merupakan kelompok suku yang masih tertutup dan hidup dengan cara lama.

Scene ini menandakan orang pedalaman Papua yang masih menggunakan kekerasan untuk menyelesaikan masalah. Scene ini senada dengan penelitian yang dilakukan Wibowo (2016) terhadap film Di Timur Matahari (2012). Dalam film itu, perang terlihat masih dilakukan orang pedalaman Papua guna melindungi diri. Wibowo mengungkapkan, secara budaya, kekerasan masih menjadi kebiasaan kelompok pedalaman Papua. Aksi membunuh merupakan pelanggaran adat yang berat bagi kelompok mereka. Mereka tidak akan pernah terima jika salah satu kelompok mereka tewas dibunuh.

Gambaran tingkah laku kekeraan seperti ini juga muncul dalam Lost in Papua. Ada scene yang menunjukkan perang terjadi karena adanya pembunuhan yang dilakukan David terhadap anggota suku Korowai. Cuplikan tersebut dapat dilihat pada scene berikut :

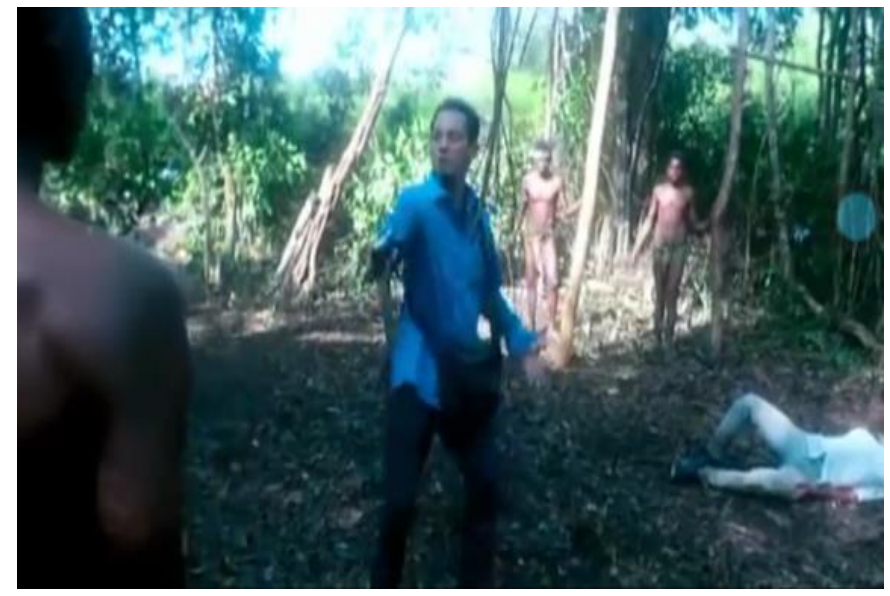

Sumber: Film Lost in Papua

Gambar 2. Menembak Anggota Suku Korowai

Gambar di atas tampak David membunuh anggota suku dengan pistol. Padahal anggota kelompok tersebut hanya ingin melerai pertengkaran David dan temannya. Pada kategori emotion dapat dilihat bahwa orang pedalaman Papua digambarkan masih memiliki pemikiran yang tidak stabil. Hal ini dilihat dari penggambaran sifat mereka yang tidak mampu menyelesaikan masalah dengan cara lebih baik. Penggambaran tersebut terjadi karena kehidupan mereka yang 
tergambar masih primitif dengan pemikiran terbelakang.

Tabel 5. Perempuan Dikurung

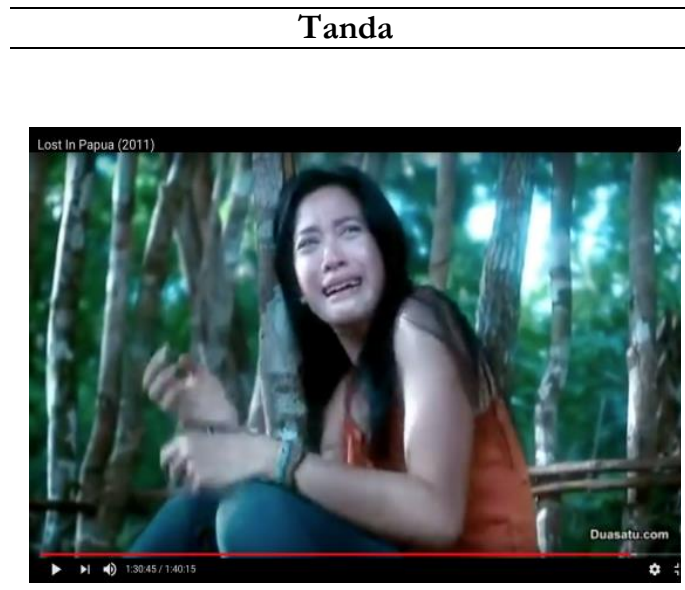

Menit 1:40:15

$\begin{array}{cc}\text { Penanda } & \text { Petanda } \\ \text { Perempuan yang } & \text { Behavior } \\ \text { berasal dari luar } & \text { Orang pedalaman } \\ \text { suku pedalaman } & \text { masih } \\ \text { Papua ditangkap } & \text { menggunakan } \\ \text { dan dipenjarakan. } & \text { kekerasan } \\ & \text { terhadap orang } \\ & \text { asing, karena } \\ & \text { mengangap orang } \\ & \text { asing sebagai } \\ & \text { musuh yang harus } \\ & \text { dimusnahkan. }\end{array}$

Emotion

Merasa takut akan keberadaan orang asing.

Intelligence

Tiadanya pendidikan formal membuat orang pedalaman tidak membuka diri terhadap orang baru atau asing.

Sumber : Film Lost In Papua

Scene di atas menggambarkan satu perempuan (dari dua yang ditangkap) yang dikurung dalam tempat yang dikelilingi kayu. Mereka dikurung oleh kelompok suku yang paling dalam selain Korowai. Suku tersebut berada di pedalaman Papua yang hanya dihuni perempuan. Tempat itu merupakan daerah terlarang yang tidak boleh dimasuki siapapun. Namun karena ingin melarikan diri dari suku Korowai, akhirnya mereka memasuki kawasan suku terlarang tersebut.

Penggambaran dalam scene ini menunjukkan bahwa orang pedalaman Papua masih menggunakan kekerasan terhadap orang asing. Orang asing dianggap sebagai musuh atau lawan yang harus dimusnahkan, orang asing dianggap akan mengancam terhadap budaya dan tradisi yang selama ini mereka lakukan. Gambaran ini menunjukkan ketertutupan yang masih sangat besar terhadap dunia luar. Orang pedalaman menganggap keberadaan orang asing di tempat mereka akan mengancam dan membahayakan keberlangsungan kehidupan mereka. Secara intelligence, pendidikan orang pedalaman dikonotasikan amat rendah. Hal ini 
terbukti dari karakter mereka yang belum mampu berinteraksi dengan orang asing. Secara emosi pun digambarkan tidak stabil.

Tabel 6. Masih Kanibal

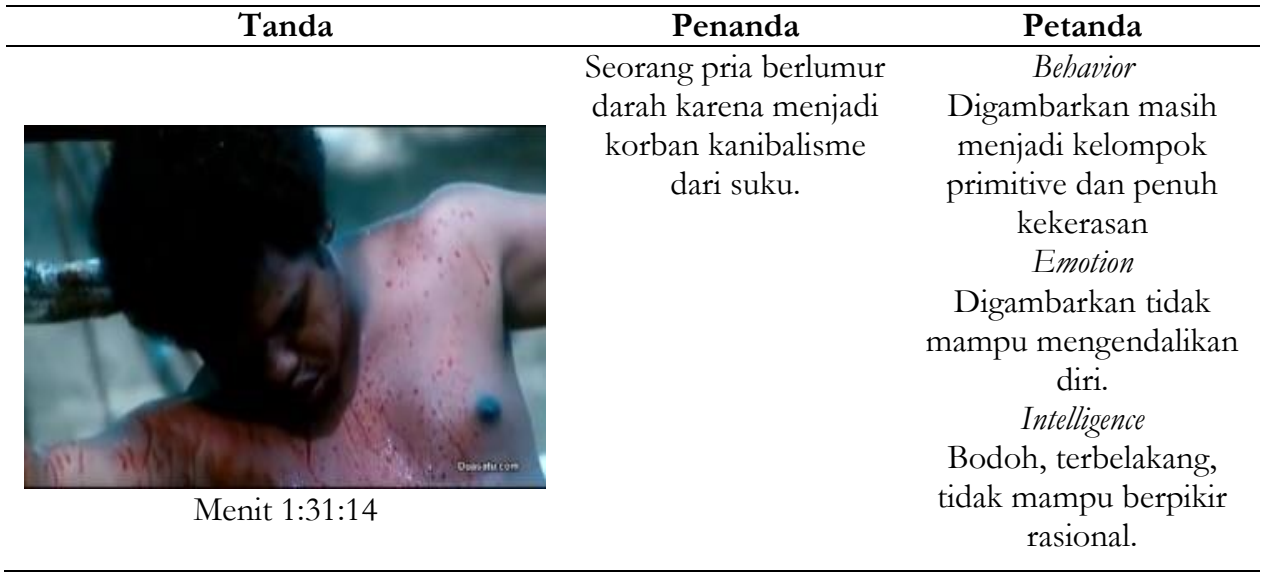

Sumber : Film Lost In Papua

Cuplikan film di atas menggambarkan seorang laki-laki yang dipasung dengan berlumur darah pada tubuhnya. Laki-laki tersebut bernama Sabo, salah satu anggota tim Nadia yang melaksanakan tugas di pedalaman Papua. Sabo merupakan salah satu korban yang terjebak di suku yang dihuni kaum perempuan. Suku terlarang tersebut masih menggunakan cara lama dalam bertahan hidup, yakni kanibalisme. Tidak diketahui secara lengkap nama dari suku ini, hanya dikatakan sebagai suku yang sangat terlarang di Papua. Suku yang anggotanya kaum perempuan ini digambarkan dalam film Lost In Papua merupakan suku yang sangat keras dan jahat.

Penggambaran kanibal ditunjukkan dalam cuplikan ini ketika Sabo dibunuh oleh kepala suku Besar dan dagingnya dibagi-bagikan kepada anggota kelompok. Gambaran ini menujukkan betapa besar tingkat keterbelakangan dan keprimitifan yang dimiliki suku pedalaman Papua. Sebelum dibunuh dan dijadikan tumbal, Sabo dan tawanan laki-laki yang lain dijadikan sebagai pemuas nafsu seksual. Suku ini melakukannya, karena ingin mencari keturunan. Kelompok ini meminta tawanan laki-laki untuk melayani mereka agar hamil dan memiliki keturunan. Namun dari tiga laki-laki yang ditawan, tak ada satupun yang mampu memberikan keturunan. Pada film Lost In Papua, kelompok tersebut memiliki kebiasaan bahwa, yang mampu memberi keturunan akan dijadikan santapan. Scene pada film ini merepresentasikan kebiasaan suku pedalaman Papua yang dianggap sebagai bagian dari pembentuk identitas. Berikut cuplikannya : 


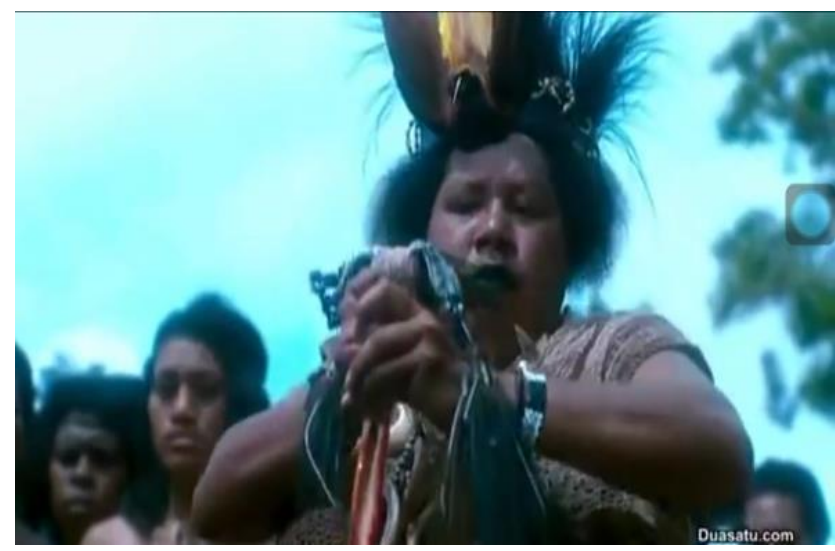

Sumber: Film Lost in Papua

Gambar 3. Kepala Duku perempuan

Scene di atas menunjukkan cara tidak biasa masih ditunjukkan oleh kelompok terlarang dalam film Lost In Papua. Mereka digambarkan tidak memiliki alternatif selain menjadikan orang lain sebagai makanannya. Digambarkan juga mereka tidak ingin membuka diri dan mengubah kebiasaan yang sangat bertolak belakang dengan dunia luar. Gambaran-gambaran realitas seperti inilah, mengutip Olivia (2011) yang akhirnya mampu mempengaruhi cara pandang audiens terhadap suatu kelompok.

Cara bertahan hidup ini mengkonotasikan tingat kecerdasan mereka masih sangat rendah. Mengutip Guerrero (1993:123), kemampuan intelegensi meliputi kemampuan mental umum yang meliputi penalaran, pengambilan informasi, mengklasifikasi, generalisasi dan menyesesuaikan diri dengan situasi baru. Hal yang dikaitkan Guererro dengan kaum minoritas kulit hitam ini memiliki kemiripan dengan kaum minoritas dalam film ini yakni pedalaman Papua ini. Kelompok suku terlarang ini masih belum bisa menyesuaikan diri dengan situasi dan kebiasaan baru.

\section{PENUTUP}

Orang pedalaman dalam film-film Indonesia pasca 1998 digambarkan secara diskriminatif dalam konteks behavior, intelligent, dan emotional. Dalam dua film yang dianalisis, yaitu Sokola Rimba dan Lost in Papua, tingkah laku (behavior) orangorang pedalaman cenderung ditampilkan dekat dengan keterbelakangan (primitif) atau jahat. Sementara secara intelligent (kecerdasan), mereka digambarkan memiliki kecerdasan rendah atau bodoh, dan secara emotional (emosi) digambarkan sebagai orang-orang dekat dengan kekerasan dan tidak mampu mencari penyelesaian jika terjadi persoalan. Gambaran-gambaran seperti ini bisa membentuk prasangka di 
Maria Rosalia., Nanang Krisdinanto, \& Brigitta Revia Sandy Fiesta

benak khalayak, yang kemudian mengkristal menjadi stereotip yang dianggap benar. Gambaran-gambaran dalam film ini mendiskriminasi orang-orang pedalaman secara kebudayaan, yang juga mencerminkan relasi kelompok mayoritas dan minoritas yang cenderung menindas.

Mengingat cukup banyaknya jumlah film-film Indonesia yang mengangkat tema orang pedalaman dari berbagai era (terutama era Orde Baru dan pasca Orde Baru) ke depan sangat menarik jika dilakukan penelitian dengan tema serupa dengan menggunakan pendekatan kuantitatif, misalnya dengan menggunakan metode analisis isi kuantitatif. Dengan metode analisis isi kuantitatif, penelitian akan mampu mengambil kesimpulan yang berupa generalisasi terhadap seluruh film-film Indonesia yang mengangkat tema orang-orang pedalaman. Dengan demikian, hasilnya bisa melengkapi hasil-hasil penelitian serupa yang menggunakan pendekatan kualitatif.

\section{DAFTAR PUSTAKA}

Christiani, L.C. (2017). Representasi Identitas Etnis Papua Dalam Serial Drama Remaja Diam-Diam Suka. Jurnal Komunikasi dan Kajian Media, 1(1), 15-30. http://jurnal.untidar.ac.id/index.php/komunikasi/issue/view/49/showT OC

Guerrero, Ed. (1993). Framing Blackness: The African American Image in Film. Philadelphia: Temple University Press.

Islam, N. (2012). Representasi Etnisitas Dalam Bingkai Bhinneka Tuggal Ika Di Media (Studi Etnis Papua dalam Bingkai Bhinneka Tuggal Ika Pada Program TransTV "Keluarga Minus"). Jurnal Dakwah Tabligh, 13(2), 235-257. http://journal.uin-alauddin.ac.id/index.php/tabligh/issue/view/43

Kaya, J.B. (2016). Representasi Homoseksual dalam Film The Imitation Game. Jurnal E-Komunikeasi, 4(1), 1-12.

http://publication.petra.ac.id/index.php/ilmu-

komunikasi/issue/view/217

Koentjaraningrat. (2009). Pengantar Ilmu Antropologi. Jakarta: PT Rineka Cipta.

Kusuma, R.S., \& Holihah, Z. (2018). Representasi Etnis Tionghoa dalam Film Ku Kejar Cinta Ke Negeri Cina dan Ngenest. MediaTor, 11(2), 165-176. DOI: https://doi.org/10.29313/mediator.v11i2.3832

Melati, K.R. (2014). Pendidikan sebagai Perekrut dalam Komunitas Terbayang: Analisa Wacana dalam Film Denias Senandung di Atas Awan. Journal of Urban Society's Arts, 1(2), 91-98.

Melissa, E. (2013). Representasi Warga Tionghoa dan Kecinaan dalam Media Kontemporer Indonesia. Jurnal Komunikasi Indonesia, 2(1), 15-22. DOI : https://doi/org/10.7454/jki.v2i1.7826

Mufid, M. (2009). Etika dan Filsafat Komunikasi. Jakarta: Prenamedia Group Olivia, F. (2011). Representasi Etnis Papua dalam Sitkom Keluarga Minus Trans TV. 1 - 
12.

Rustandi, R. (2018). Analisis Wacana Kritis Komodifikasi Daí dalam Program Televisi. Communicatus: Jurnal Ilmu Komunikasi, 2(2), 197-222. DOI: $10.15575 /$ cjik.v2i2.4949

Saleh, S. (2014). Agama Kepercayaan, Dan Kelestarian Lingkungan Studi Terhadap Gaya Hidup Orang Rimba Menjaga Lingkungan di Taman Nasional Bukit Dua Belas (TNBD). Jambi, 4(3), 312-322. DOI: https://doi.org/10.22146/kawistara.6386

Sidik, H. (2016). Impresi Orang Rimba:"Melangun” Sebuah Komposisi Musik dalam Interpretasi Perjalanan Orang Rimba. Journal Puitika, 12(2), 122-134. http://jurnalpuitika.fib.unand.ac.id/index.php/jurnalpuitika/issue/view/8

Sobur, A. (2016). Semiotika Komunikasi. Bandung: PT Remaja Rosdakarya

Sunarto, K. (2004). Pengantar Sosiologi. Jakarta: Universitas Indonesia.

Syarifin, A. (2014). Kuaso Betino Rimbo. Jurnal Ilmiah Kajian Gender, 4(2), 157-180. DOI: http://dx.doi.org/10.15548/jk.v4i2.97

Vera, N. (2014). Semiotika dalam Riset Komunikasi. Bogor: Ghalia Indonesia.

Wibowo, I.S.W. (2016). Representasi Kearifan Lokal dalam Film di Timur Matahari. Jurnal Multimedia Nusantara, 1063-1078.

Widjaja, A. (2016). Representasi Resistensi Rasisme. Film 12 Years a Slave.

Yusuf, I. (2005). Media: Kematian dan Identitas Budaya Minoritas. Yogyakarta: UII Preslarasatis. 
Maria Rosalia., Nanang Krisdinanto, \& Brigitta Revia Sandy Fiesta 